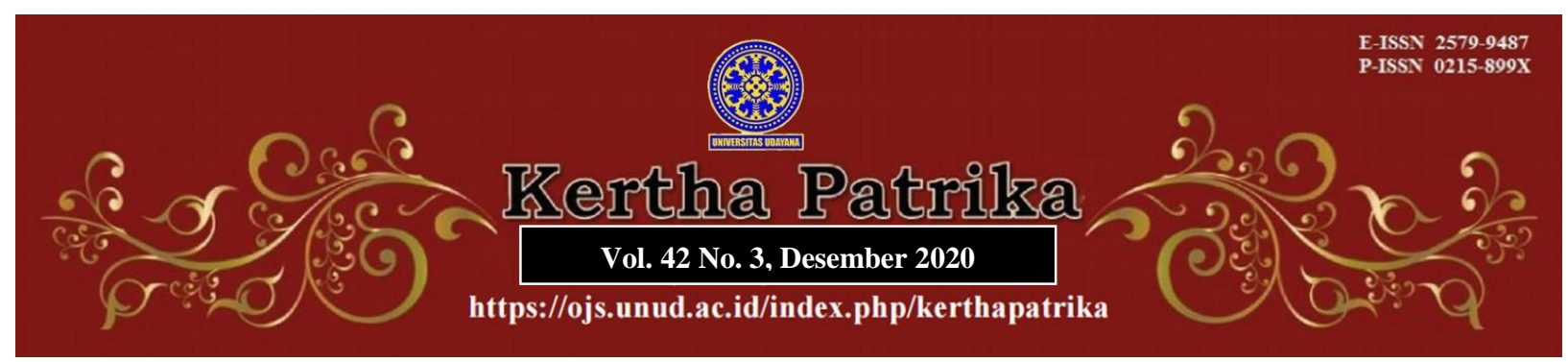

\title{
Diversi sebagai Bentuk Perlindungan Anak dalam Sistem Peradilan di Indonesia
}

\section{Ni Ketut Ayu Suwandewi, ${ }^{1}$ Ni Nengah Adiyaryani ${ }^{2}$}

1Pusaka Bali Law Office, E-mail: ayu22376@gmail.com

2Fakultas Hukum Universitas Udayana, E-mail: nengah_adiyaryani@unud.ac.id

\begin{tabular}{l}
\hline Info Artikel \\
\hline Masuk : 10 September 2020 \\
Diterima : 29 Desember 2020 \\
Terbit : 31 Desember 2020 \\
Keywords : \\
Diversion; Legal Protection; \\
Criminal Justice System for \\
Children \\
\\
Corresponding Author: \\
Ni Ketut Ayu Suwandewi, \\
-mail: ayu22376@gmail.com \\
Kata Kunci: \\
Disteri; Perlindungan Hukum; \\
\end{tabular}

\begin{abstract}
Children are entities whose rights must be protected and upheld by every country in the world. Indonesia's commitment to providing child protection is reflected in Article 28 B paragraph (2) of the 1945 Constitution of the Republic of Indonesia. Providing protection by the state is not only in protecting children as victims and witnesses, but also in ensuring that children in conflict with the law receive adequate legal protection. Law Number 11 of 2011 concerning the Criminal Justice System for Children (UU SPPA) is a basic guideline in protecting children in conflict with the law, although it still provides limitations regarding the qualifications of children as criminal offenders who are entitled to undergo a diversion process. This study aims to analyze the protection arrangements for children in conflict with the law and diversion as a form of child protection in the justice system in Indonesia. This article is a normative legal research using a statutory approach and a conceptual approach. The results of the study suggest that the provisions regarding the protection of children in conflict with the law are contained in various laws and regulations, especially the national legislations that regulate child welfare, child protection, human rights, and the juvenile criminal justice system. Diversion is a form of legal protection for children in conflict with the law. Thus, handling cases of children in conflict with the law at the level of the police, prosecutors, and examinations in court are obliged to seek diversion.
\end{abstract}




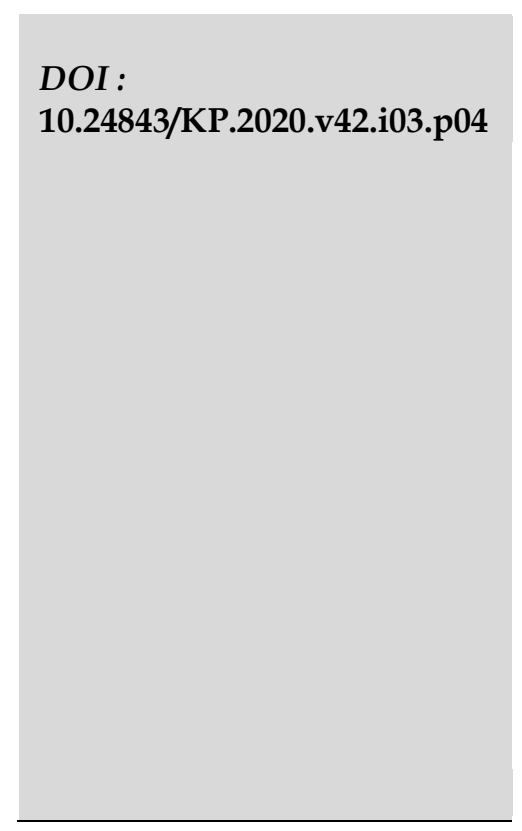

sebagai pelaku tindak pidana yang berhak untuk menjalani proses diversi. Penelitian ini bertujuan menganalisis pengaturan perlindungan terhadap anak yang berkonflik dengan hukum dan diversi sebagai bentuk perlindungan anak dalam sistem peradilan di Indonesia. Artikel ini merupakan penelitian hukum normatif dengan menggunakan pendekatan perundang-undangan dan pendekatan konseptual. Hasil studi menunjukan bahwa pengaturan mengenai perlindungan terhadap anak yang berkonflik dengan hukum tertuang di berbagai peraturan perundang-undangan, khususnya undang-undang yang mengatur tentang kesejahteraan anak, perlindungan anak, hak asasi manusia, dan sistem peradilan pidana anak. Diversi merupakan bentuk perlindungan hukum bagi anak yang berkonflik dengan hukum. Dengan demikian, penanganan kasus anak yang berkonflik dengan hukum pada tingkat kepolisian, kejaksaan dan pemeriksaan di pengadilan wajib mengupayakan diversi.

\section{Pendahuluan}

Setiap negara di dunia anak menjadi bagian generasi yang merupakan potensi bagi kemajuan serta penerus bagi perjuangan bangsa dalam mencapai cita-citanya. Anak merupakan entitas yang wajib diberikan perlindungan serta dijunjung tinggi hakhaknya oleh setiap negara di dunia. Setiap anak nantinya akan memikul tanggung jawab memajukan bangsa sehingga kesempatan yang sama dalam perkembangan yang optimal sangat diperlukan bagi fisik, mental sosial dan moral anak, berbagai peraturan yang mengatur secara tegas mengenai perlindungan hukum terhadap anak telah banyak disusun dan disahkan oleh negara-negara maupun secara internasional yang kemudian diratifikasi oleh berbagai negara di dunia.

Perlindungan hukum (legal protection) tersebut sebaiknya diterapkan bagi anak bahkan ketika ia belum dilahirkan kedunia atau masih dalam kandungan. ${ }^{1}$ Hak-hak anak diakui dan dilindungi dengan pengaturan di berbagai peraturan internasional salah satunya Konvensi Hak Anak (Convention on the Rights of the Child) antara lain hak-hak sipil, politik, sosial dan budaya yang tentu saja bersumber dari pemenuhan hak asasi manusia.

Negara Indonesia telah menunjukkan komitmennya dalam mengupayakan perlindungan terhadap anak yang ditegaskan dalam konstitusi yang merupakan dasar dari semua peraturan perundang-undangan, komitmen tersebut tercetak pada Pasal 28 B ayat (2) Undang-Undang Negara Republik Indonesia Tahun 1945 (selanjutnya disebut UUD 1945) yang mengatur bahwa sudah menjadi kewajiban negara memberikan hak anak berupa kelangsungan hidup, terjaminnya pertumbuhan dan perkembangan anak tanpa adanya kekerasan dan diskriminasi. Pengaturan secara tegas tersebut bertujuan agar anak senantiasa memperoleh pendidikan yang berkualitas, tumbuh dan

1 Sri Utari, A.A. (2018). Efektivitas Peraturan Daerah Provinsi Bali Nomor 6 Tahun 2014 tentang Perlindungan Anak dalam Aspek Hak Anak atas Pendidikan. Jurnal Kertha Negara 6 (2), 1-10, h.3. 
berkembang pada lingkungan yang sehat, aman dan melindungi serta tidak dapat dipungkiri diaturnya kebijakan nasional perlindungan di dalam konstitusi memberikan konsekuensi undang-undang dibawahnya tidak boleh mengatur hal yang bertentangan. ${ }^{2}$

Lingkungan sosial dan penanaman nilai-nilai yang ada di keluarga sangat mempengaruhi anak dalam proses perkembangannya menuju dewasa. Maraknya sikap sewenang-wenang secara tidak langsung memberikan dampak terganggunya proses tumbuh dan kembang secara sehat. ${ }^{3}$ Lingkungan sosial dan penanaman nilai yang salah dapat mengarahkan anak menjadi kelompok yang rentan menjadi anak yang melakukan kenakalan atau kejahatan. Seperti diketahui, bahwa kualifikasi anak berhadapan hukum tediri dari anak sebagai korban, pelaku, dan saksi dalam peristiwa pidana. ${ }^{4}$ Berbagai pelanggaran serta kejahatan oleh anak tidak murni dari anak itu sendiri namun merupakan suatu buah hasil dari pola perilaku menyimpang, yang melalui proses panjang. Anak yang berkonflik dengan hukum dapat berasal dari latar belakang kalangan sosial ekonomi tinggi, menengah maupun bawah dikarenakan tidak dipenuhinya kebutuhan secara rohani dan jasmani. ${ }^{5}$

Pemberian perlindungan oleh negara tidak hanya melindungi anak sebagai korban maupun saksi, namun negara juga berkewajiban dalam memberikan perlindungan terhadap anak berkonflik hukum atau sebagai pelaku tindak pidana. Anak yang menjadi pelaku dalam suatu peristiwa pidana sangat rentan terhadap penegakan hukum yang jauh dari keadilan, bahkan proses penegakannya sama persis dengan yang diterapkan terhadap pelaku tindak pidana dewasa. Anak tentu sangat berbeda dengan orang dewasa, baik secara pola pikir, psikologis maupun fisiknya sehingga menjadi pertimbangan ketika anak telah melakukan suatu tindak pidana maka ia melakukannya dengan pola pikir dan psikologis yang jauh berbeda dengan orang dewasa. Sangat tidak adil apabila proses pemidanaan anak disetarakan dengan orang dewasa. Tindakan tersebut berdampak pada terampasnya kebebasan dan menstigmasi anak sehingga melahirkan penjeraan apabila proses penegakan tidak dilaksanakan dengan tepat. 6 Sebaliknya yang terjadi yaitu anak dihukum tanpa mempertimbangkan rasa keadilan dengan memperlakukan cara yang sama terhadap anak seperti yang diterapakan pada orang dewasa. Apabila hal ini terus terjadi, tentu hal ini menjadi mimpi buruk bagi negara, apabila generasi muda yang diharapkan menjadi penerus bangsa terkukung dalam sistem pemidanaan yang tidak tepat.

2 Said, M. F. (2018). Perlindungan Hukum Anak Dalam Perspektif Hak Asasi Manusia. JCH (Jurnal Cendekia Hukum), 4(1), 141-152. DOI: http://doi.org/10.33760/jch.v4i1.97, h.142.

3 Sari, M. A. C. M. (2013). Diversi dalam Sistem Peradilan Pidana Anak di Indonesia. Jurnal Magister Hukum Udayana, 2(1), 44093. DOI: https://doi.org/10.24843/JMHU.2013.v02.i01.p05, h. 3 .

${ }^{4}$ Urbas, G. (2000). The age of criminal responsibility (Vol. 181). Canberra, Australian Capital Territory: Australian Institute of Criminology, h.3.

5 Sinaga, S. M., \& Lubis, E. Z. (2010). Perlindungan Hukum terhadap Anak Yang Melakukan Kejahatan dalam Persidangan Anak. Jurnal Mercatoria, 3(1), 52-57. DOI: https://doi.org/10.31289/mercatoria.v3i1.595, h.54.

${ }^{6}$ Budoyo, S., \& Sari, R. K. (2019). Eksistensi Restoratif Justice sebagai Tujuan Pelaksanaan Diversi pada Sistem Peradilan Anak di Indonesia. Meta-Yuridis, 2(2), 79-90. DOI: https:// doi.org/10.26877/m-y.v2i2.4689, h.79. 
Berbagai macam pengertian dan batasan usia seseorang dapat dikategorikan sebagai anak, hal ini secara tidak langsung berdampak bagi penerapan sistem pertanggungjawaban bagi anak yang melakukan suatu tindak pidana atau kejahatan. Tentu keberagaman tersebut merupakan hal yang wajar terjadi, mengingat penentuan batasan kualifikasi anak terpengaruh dari faktor sistem hukum negara yang dianut maupun terpengaruh dari berbagai aspek seperti ekonomi, sosial, politik dan sosiokultural negara bersangkutan. ${ }^{7}$

Proses penindakan anak pelaku pidana telah diatur pada berbagai instrumen nasional di berbagai negara tentunya berakar dari instrument Internasional salah satunya Article 37 Convention on the Rights of the Child yang menegaskan " provides "the arrest, detention or imprisonment of a child shall be in conformity with the law and shall be used only as a measure of last resort" sehingga proses penangkapan kemudian menjadi penahanan harus dijadikan upaya akhir. Negara-negara yang menandatangani berkewajiban mempromosikan langkah-langkah penanganan tanpa menggunakan proses pengadilan dan menyediakan berbagai disposisi seperti perawatan, bimbingan, penyuluhan untuk memastikan anak-anak ditangani dengan cara yang memenuhi kesejahteraan mereka dan sesuai dengan keadaan dan pelanggaran mereka. ${ }^{8}$

Negara Indonesia sendiri yang sudah menjadikan perlindungan anak sebagai kewajiban yang sangat penting, melakukan suatu upaya dalam rangka menanggulangi tindak pidana anak hal ini terbukti dengan adanya sistem peradilan pidana khusus anak. Proses penanganan ini diharapkan mampu menjadi payung yuridis bagi anak sehingga dapat diutamakannya kepentingan anak tersebut, yang menjadi titik fokusnya tidak lain ialah pemulihan yang menjadi pemenuhan bagi kesejahteraan anak dan tetap memberikan keadilan bagi korban peristiwa pidana tersebut, sehingga merupakan hal yang penting ketika penanganan perkara anak dibedakan secara khusus dengan penanganan perkara orang dewasa.

The law as a social rule cannot be separated from the values that apply in a society, it can even be said that the law is a reflection and concretization of the values that existed once in force in society. ${ }^{9}$ (terjemahan bebas : hukum sebagai kaidah sosial tidak terlepas dari nilai-nilai yang berlaku dalam masyarakat, bahkan dapat dikatakan bahwa hukum merupakan cerminan dan konkretisasi dari nilai-nilai yang pernah ada dan berlaku dalam masyarakat). Peran hukum sebagai kaidah sosial mendasari terbentuknya berbagai instrumen hukum, dalam hal ini yang mengatur mengenai pemberian perlindungan anak bersentuhan dengan hukum yaitu diantaranya Undang-Undang Nomor 39 Tahun 1999 tentang Hak Asasi Manusia (selanjutnya disebut UU HAM),Undang- Undang Nomor 4 Tahun 1979 tentang Kesejahteraan Anak (selanjutnya disebut UU Kesejahteraan Anak), Undang-Undang Nomor 23 Tahun 2002 tentang Perlindungan

7 Sekhroni, S. (2016). Criminal Liability dan Diversi Terhadap Tindak Pidana Anak dalam Sistem Peradilan Anak di Indonesia. UNIFIKASI: Jurnal Ilmu Hukum, 3(1), 36-64. DOI: https:// doi.org/10.25134/unifikasi.v3i1.405, h.40.

8 Ratomi, A. (2013). Konsep Prosedur Pelaksanaan Diversi pada Tahap Penyidikan dalam Penyelesaian Tindak Pidana yang Dilakukan oleh Anak. Arena Hukum, 6(3), 394-407. DOI: https:// doi.org/10.21776/ub.arenahukum.2013.00603.6 h.396.

9 Sudiarawan, K. A., Tanaya, P. E., \& Hermanto, B. (2020). Discover the Legal Concept in the Sociological Study. Substantive Justice International Journal of Law, 3(1), 94-108. DOI: http://dx.doi.org/10.33096/sjiil.v3i1.69, h.96. 
Anak sebagaimana diubah menjadi Undang-Undang Nomor 35 Tahun 2014 Perlindungan Anak (selanjutnya disebut UU Perlindungan Anak). Peraturan tersebut menjunjung dan memuat hal-hal fundamental perlindungan anak seperti pengutamaan kepentingan terbaik bagi anak tanpa diskriminasi atau tebang pilih. Namun sayangnya pada penerapan undang-undang tersebut belum dapat dirasakan oleh anak berkonfik hukum secara merata. 10

Penyelenggaraan sistem peradilan pidana anak dalam implementasinya masih belum mewujudkan tujuan kesejahteraan anak dan kepentingan terbaik bagi anak. Pidana penjara bagi anak menunjukkan adanya kecenderungan bersifat merugikan perkembangan jiwa anak di masa mendatang. Apabila mayoritas anak yang berkonflik dengan hukum dihadapkan pada sistem peradilan pidana, kemudian hakim menjatuhkan pidana penjara maka hak-hak mereka yang dijamin oleh undang-undang banyak yang tidak terpenuhi. Selain hal itu dengan adanya keterbatasan jumlah rumah tahanan dan Lembaga Pemasyarakatan (Lapas) Anak, maka anak yang berkonflik dengan hukum sering digabung dengan tahanan dewasa. ${ }^{11}$

Seorang anak yang melakukan tindak pidana dalam penanganannya harus dibedakan dengan pelaku orang dewasa, dikarenakan secara psikologis dan kemampuan berpikir anak belum tumbuh dengan sempurna sehingga dibutuhkan kebijakan dan penanganan yang tepat tanpa mengesampingkan hak-hak anak, kepentingan korban maupun masyarakat secara keseluruhan. Untuk menghindari dampak negatif proses peradilan pidana terhadap anak, United Nations Standard Minimum Rules for the Administration of Juvenile Justice (The Beijing Rules) memberikan kewenangan kepada aparat penegak hukum untuk menangani masalah anak yang berkonflik hukum dengan tidak mengambil jalan formal serta menyerahkan kepada masyarakat dan bentuk-bentuk kegiatan pelayanan sosial lainnya. ${ }^{12}$

Undang -Undang Nomor 11 Tahun 2011 tentang Sistem Peradilan Pidana Anak (selanjutnya disebut UU SPPA) sebagai ujung tombak upaya pemberian perlindungan pada anak sebagai pelaku pidana. Pada pengaturannya, UU SPPA telah mengatur mengenai upaya diversi sebagai bentuk perlindungan terhadap anak yang berkonflik dengan hukum namun masih memberikan batasan mengenai kualifikasi anak sebagai pelaku tindak pidana yang berhak untuk menjalani proses diversi.

Adapun dalam penulisan ini memiliki tujuan umum yakni untuk menganalisis Diversi sebagai Bentuk Perlindungan Anak pada Sistem Peradilan di Indonesia. Tujuan khusus penulisan ini yaitu menganalisis pengaturan mengenai perlindungan terhadap anak yang berkonflik dengan hukum serta menganalisis diversi sebagai bentuk perlindungan anak dalam sistem peradilan di Indonesia. Kajian ini menjadi sangat penting dan relevan untuk dilaksanakan mengingat maraknya kasus anak berkonflik dengan hukum yang memerlukan penanganan yang tepat. Penelitian ini diharapkan dapat menjadi pedoman dalam Sangat diharapkan penelitian ini bermanfaat bagi mahasiswa dan masyarakat luas.

10 Ibid, h.401.

11 Wahyudi, S. (2011). Implementasi ide diversi dalam pembaruan sistem peradilan pidana anak di Indonesia. Yogyakarta: Genta Pub., h.3.

12 Ibid, h.4. 


\section{Metode Penelitian}

Jenis penelitian penulis yaitu penelitian normatif untuk menganalisis dan mengkaji mengenai pengaturan perlindungan terhadap anak yang berkonflik dengan hukum dan diversi sebagai bentuk perlindungan anak dalam sistem peradilan di Indonesia. Jenis pendekatan yang dipergunakan pada penelitian yakni pendekatan perundang undangan (statute approach), dan pendekatan konseptual (conceptual approach). Bahan hukum primer dan sekunder menjadi sumber dari penelitian penulis. Teknik untuk mengkaji dan mengumpulkan bahan hukum tersebut menggunakan studi dokumenter kemudian diolah melalui teknis analisis kualitatif yang memberikan deskripsi dengan kata-kata atas temuan-temuan tersebut.

\section{Hasil Dan Pembahasan}

\subsection{Pengaturan mengenai Perlindungan terhadap Anak yang Berkonflik dengan Hukum}

Pembahasan mengenai perlindungan hukum terhadap anak berkaitan dengan pemberian hak-hak anak. Perlindungan anak tidak lain merupakan segala kegiatan untuk menjamin dan memberikan perlindungan pada anak beserta hak-haknya agar dapat hidup, tumbuh berkembang, dan berpartisipasi secara optimal sesuai harkat dan martabat kemanusiaan serta mendapat perlindungan dari kekerasan dan diskriminasi. Anak berhak atas kesejahteraan, perawatan, asuhan, bimbingan berdasarkan kasih sayang baik dalam keluarganya maupun di dalam asuhan khusus untuk tumbuh kembang dengan wajar. Perlindungan hak-hak anak sangat ditentukan oleh adanya kebijakan perlindungan anak (Child Protection Policy), kebijakan kesejahteraan anak (Child Welfare Policy). Negara Indonesia telah berkomitmen menjadikan perlindungan anak sebagai hal yang paling mendasar, hal ini tercermin dari pengaturan mengenai yang diatur secara tegas dalam konstitusi.

Pada UU Perlindungan Anak menyatakan bahwa Anak yang berkonflik dengan hukum berhak mendapat perlakuan secara manusiawi dan penempatannya terpisah dari orang dewasa, memperoleh bantuan hukum atau bantuan lain sesuai tahapan upaya hukum yang berlaku dan membela diri dan memperoleh keadilan yang objektif di depan pengadilan yang tidak memihak. Pemberian perlindungan khusus bagi anak yang berhadapan dengan hukum khususnya yang berkonflik dengan hukum merupakan kewajiban dan tanggung jawab negara sebagaimana diatur dalam Pasal 64 UU Perlindungan Anak, dilaksanakan dalam bentuk-bentuk sebagai berikut:

a) Perlindungan atas anak secara manusiawi sesuai dengan martabat dan harkat anak

b) Penyediaan petugas pedampingan khusus anak sejak dini

c) Penyediaan sarana dan prasarana khusus

d) Penjatuhan sanksi yang tepat untuk kepentingan yang terbaik bagi anak

e) Pemantauan dan pencacatan terus menerus terhadap perkembangan anak yang berhadapan dengan hukum

f) Pemberian jaminan untuk mempertahankan hubungan dengan orang tua atau keluarga; dan

g) Perlindungan dari pemberitaan identitas melalui media massa dan untuk menghindari labelisasi 
Pasal 16 ayat (1), (2), (3) UU Perlindungan Anak menyatakan bahwa setiap anak berhak memperoleh perlindungan dari sasaran penganiayaan, atau penjatuhan hukuman yang tidak manusiawi. Setiap anak berhak untuk memperoleh kebebasan sesuai dengan hukum. Penangkapan, penahanan atau tindak pidana penjara anak hanya dilakukan apabila sesuai dengan hukum yang berlaku dan hanya dapat dilakukan sebagai upaya terakhir.

Pada UU HAM mengatur perlindungan anak dan hak-hak anak dalam Pasal 52 sampai dengan Pasal 66. Adapun hak anak yang berkonflik dengan hukum juga diatur dalam undang-undang ini yaitu pada Pasal 66 ayat(1), (2), yang mana menegaskan bahwa setiap anak berhak untuk tidak dijadikan sasaran penganiayaan, penyiksaan, atau penjatuhan hukuman yang tidak manusiawi. Hukuman mati atau hukuman seumur hidup tidak dapat dijatuhkan untuk pelaku tindak pidana yang masih anak. Lebih lanjut dinyatakan bahwa setiap anak berhak untuk tidak dirampas kebebasannya secara melawan hukum, penangkapan, penahanan atau pidana penjara anak hanya boleh dilakukan sesuai dengan hukum yang berlaku dan hanya dapat dilaksanakan sebagai upaya terakhir. Merupakan bagian dari hak anak yaitu memperoleh perlindungan dari sasaran penganiayaan, penyiksaan, atau penjatuhan hukuman yang tidak manusiawi.

Berbagai ketentuan pada undang-undang tersebut tampak sesuai dengan tujuan ide diversi, karena terdapat kesamaan tujuan ide diversi dan tujuan perlindungan khusus yang diberikan kepada anak yang berhadapan dengan hukum, berupa perlakuan atas anak secara manusiawi sesuai dengan martabat dan harkat anak serta menghindari labelisasi terhadap anak yang berkonflik dengan hukum.

\subsection{Diversi sebagai Bentuk Perlindungan Anak dalam Sistem Peradilan di Indonesia}

Penuntasan perkara anak diatur secara tegas pada UU SPPA. Sistem peradilan ini tidak lain merupakan proses penanganan terhadap anak berhadapan dengan hukum dari yang mulai tahapan penyelidikan hingga pembinaan usai menjalani pidana. Pelaksanaan sistem peradilan pidana anak berpedoman pada beberapa asas yang yang salah satunya ialah asas non diskriminasi dan pemidanaan sebagai upaya terakhir (ultimum remidium)

Beberapa asas tersebut menunjukan bahwa undang-undang SPPA mengedepankan proses peradilan tanpa tujuan pembalasan dan perampasan kemerdekaan. Berbagai pengaturan mengenai perlindungan anak yang salah satunya terdapat dalam UU SPPA, yang mengutamakan keadilan restoratif sebagai hal paling utama dalam penanganan anak yang berkonflik dengan hukum. Hal ini mencerminkan bahwa segala proses peradilan yang harus di lalui oleh anak yang berkonflik dengan hukum menggunakan pendekatan restorative justice. Penyelenggaraan sistem peradilan tersebut di negara Indonesia bertujuan untuk mewujudkan kesejahteraan anak. ${ }^{13}$ Sistem peradilan dengan paradigma restoratif bertujuan tercapainya indikator hal-hal perbaikan yang telah

13 Bramita, F., \& Cahyaningtyas, I. (2018). Children Hearing System sebagai Ide Pembaharuan Sistem Peradilan Pidana Anak di Indonesia. Jurnal Magister Hukum Udayana (Udayana Master Law Journal) 7(4), 529-545. DOI: https://doi.org/10.24843/JMHU.2018.v07.i04.p08, h.535. 
disepakati, upaya menghindari stigma/label jahat (labeling) serta menghindari prisonisasi terhadap anak yang berkonflik dengan hukum. ${ }^{14}$

Adapun skema yang menggambarkan penerapan diversi sebagai upaya dalam mencapai keadilan restoratif :

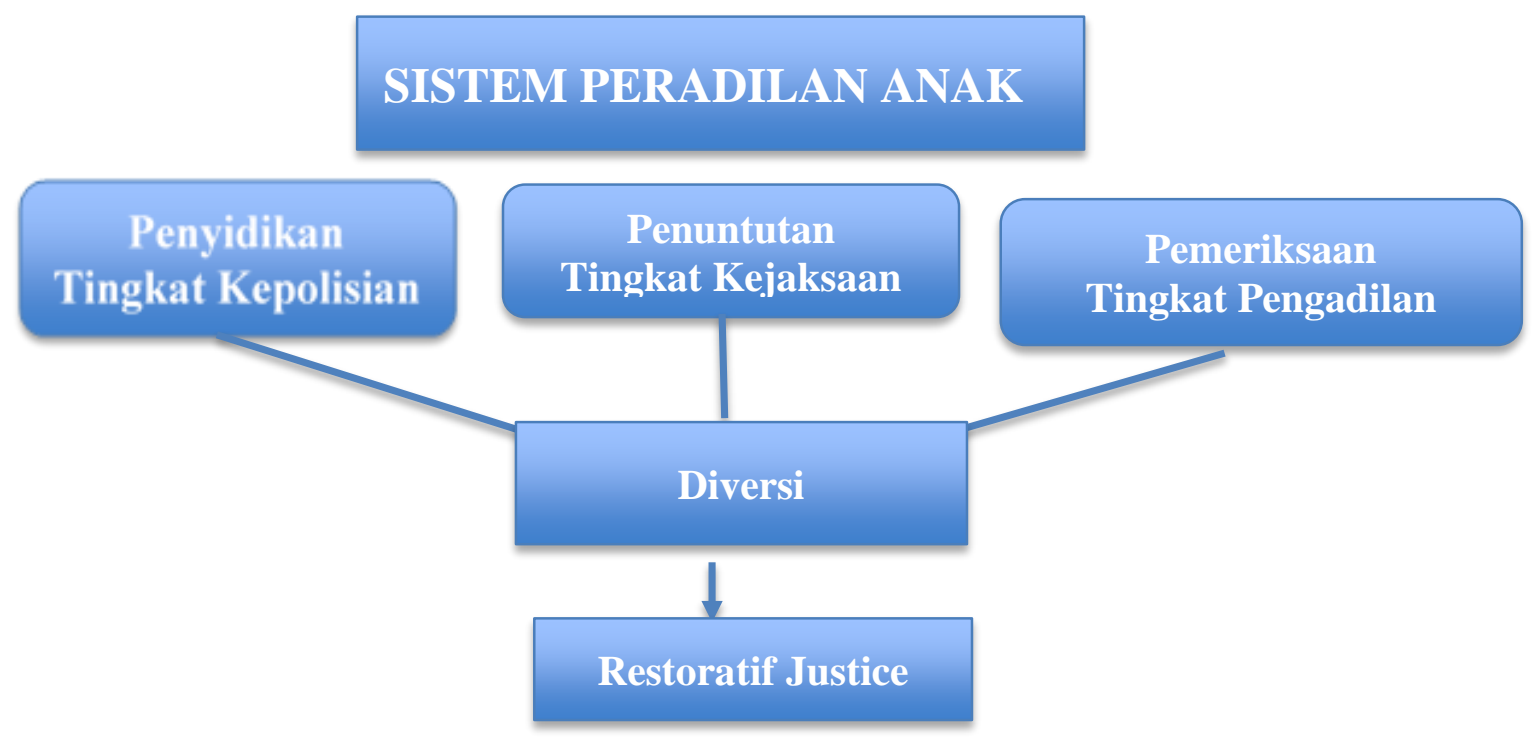

Berdasarkan skema diatas restorative justice pada penanganan anak yang berkonflik dengan hukum dapat diupayakan pada tingkat penyidikan, penuntutan, pemeriksaan melalui upaya diversi. Keadilan restoratif yang merupakan penyelesaian perkara tindak pidana dengan melibatkan pelaku, korban, keluarga pelaku/korban dan pihak lain untuk bersama-sama mencari penyelesaian yang adil dengan menekankan pemulihan kembali pada keadaan semula dan bukan pembalasan. Gagasan model penyelesaian kasus anak akhirnya menemukan titik terang yaitu berdasarkan model keadilan restoratif. Keadilan restorative telah mewarnai perkembangan hukum di dunia dan menjadi terobosan demi keadilan bagi semua pihak. ${ }^{15}$ Keadilan restoratif memandang bahwa perilaku delinkuensi anak menyebabkan kerugian kepada korban dan masyarakat, maka melalui model restorative justice tidak hanya menimbulkan efek jera kepada anak yang melakukan kejahatan, namun berfokus pada perbaikan kerugian dan penyembuhan pada korban dan masyarakat. Peradilan restoratie tidak lain merupakan upaya restorasi kesejahteraan masyarakat melalui upaya-upaya yang mengarahkan anak agar bertanggungjawab atas perbuatannya. Upaya tersebut menitikberatkan pada perbaikan terhadap korban, pengakuan pelaku terhadap masyarakat, upaya rekonsiliasi dan konsiliasi dengan korban serta masyarakat. Pelaku, korban, masyarakat dan penegak hukum memiliki perannya masing-masing, pelaku yang berperan dalam merestorasi kerugian korban, korban yang berperan bagi penentuan sanksi terhadap

14 Wahyudi, S., Op.cit, h.39.

15 Hariyanto, D. R. S., \& Yustiawan, D. G. P. Paradigma Keadilan Restoratif Dalam Putusan Hakim. Kertha Patrika, 42(2), 180-191. DOI: https:/ / doi.org/10.24843/KP.2020.v42.i02.p06, h.185. 
pelaku, masyarakat bertindak sebagai mediator dan penegak hukum yang memfasilitasi adanya mediasi tersebut. ${ }^{16}$

Pada proses pelaksanaan peradilan anak, kesejahteraan anak harus menjadi pertimbangan utama, lebih lanjut bahwa wajib memberikan pertimbangan untuk pelaku remaja dalam proses hukumnya tanpa menggunakan pengadilan formal oleh polisi, kejaksaan dan lembaga lainnya. ${ }^{17}$ Untuk itu dalam memfasilitasinya upaya yang sangat mendesak dilaksanakan adalah pengawasan dan bimbingan masyarakat yang memadai, restitusi dan memberikan kompensasi kepada korban. Pengalihan dari peradilan formal dan informal menjadi program masyarakat dalam prakteknya memiliki fungsi untuk memperhambat efek negatif dalam proses peradilan anak yang biasanya berupa stigma hukuman, dalam hal ini dikhususkan pada pelanggaran yang bersifat tidak serius.

Pada dasarnya dilaksanakannya diversi sangat berhubungan dengan upaya dalam memberikan perlindungan pada anak pelaku pidana. Diversi dilakukan untuk menyediakan perlindungan dan rehabilitasi kepada anak pelaku pidana untuk mencegah anak nantinya terlibat dalam kejahatan yang sama atau bahkan lebih berat. ${ }^{18}$ Diversi juga merupakan solusi dalam mencegah pelaku tindak pidana anak menjadi residivis maupun menjadi penjahat ketika sudah dewasa. Alasan utama diterapkannya pengutamaan diversi yang dikemukakan oleh UNICEF yaitu negara memiliki kewajiban untuk memastikan bahwa anak-anak pelaku pidana mendapatkan manfaat, mengurangi jumlah pelanggaran ringan dan kurang serius sehingga sistem peradilan dan penahanan formal dapat lebih difokuskan pada residivis atau pengulangan tindak pidana. Selain itu diversi juga bertujuan dalam mencegah anak mengalami dampak perkembangan negatif terkait dengan penahanan dan proses formal yang meminimalisir terjadinya stimatisasi atau pelabelan anak (dan keluarga mereka). ${ }^{19}$

Pentingnya diversi sebagai alternatif yang memiliki misi untuk menjauhkan anak dari pemidanaan mengingat pidana penjara cenderung berdampak buruk bagi tumbuh dan kembang anak di masa depan. Diprosesnya anak pelaku pidana ini melalui sangat memungkinkan hakim menjatuhkan pidana sehingga merampas kemerdekaan anak. Selain hal tersebut dengan kondisi yang sangat memperihatinkan yaitu terbatanya rumah tahanan dan lapas anak mengarahkan pada suatu kondisi anak ditempatkan bersama tahanan yang sudah dewasa.

Diversi merupakan hal yang penting dalam proses upaya rehabilitasi anak pelaku pidana. Tahapan ini memungkinkan penanganan anak tersebut tanpa menstigmatisasi melalui label resmi namun memberikan perawatan dan rehabilitasi yang memadai. Ide diversi sebagai bentuk pengalihan penangan kenakalan anak dari proses peradilan anak konvensional, kea rah penanganan anak yang bersifat pelayanan kemasyarakatan dan

16 Wahyudi, S., Loc.cit.

17 Swardhana, G.M. (2013). Kenakalan Anak \& Upaya Penanggulangannya. Udayana University Press, h.3.

18 Ananda, F. (2018). Penerapan Diversi Sebagai Upaya Perlindungan Hukum Terhadap Anak Pelaku Tindak Pidana. Jurnal Daulat Hukum, 1(1), 77-86. DOI: http://dx.doi.org/10.30659/jdh.v1i1.2566, h.80. 
ide diversi dilakukan untuk menghindarkan anak pelaku dari dampak negative praktek penyelenggaraan peradilan anak. ${ }^{20}$

Diversi dapat mengalihkan anak yang telah melakukan pelanggaran ringan menjauhkan dari pemidanaan dan menuju perawatan berbasis masyarakat dalam mencegah kenakalan di masa depan. Mengingat bahwa pemidanaan terhadap anak dapat melanggengkan kenakalan melalui "pelabelan" atau stigmatisasi dan memaparkan remaja dalam keadaan di dalam lembaga pemasyarakatan justru memungkinkan meningkatkan kenakalan remaja. ${ }^{21}$ Nilai-nilai kekeluargaan yang menjadi nilai dasar dalam proses pelaksanaan diversi. ${ }^{22}$ Bentuk diversi adalah dalam bentuk tindakantindakan mengalihkan pemeriksaan perkara yang dapat menghentikan atau melepaskan anak dari proses peradilan pidana serta anak diserahkan kepada orang tua/walinya ataupun diserahkan kepada masyarakat atau dinas sosial untuk dididik.

Diversi di Indonesia wajib diupayakan pada tingkat kepolisian, kejaksaan dan pada pemeriksaan di pengadilan anak, terdapat batasan penerapan diversi diatur secara tegas dalam UU SPPA antara lain diversi dilakukan terhadap tindak pidana dengan ancamannya dibawah 7 (tujuh) tahun serta bukan suatu pengulangan kejahatan (residivis). Anak pelaku pidana yang diancam 7 (tujuh) tahun keatas tidak dapat diterapkan diversi apabila mengacu pada UU SPPA ini. Anak-anak dibawah 12 tahun merupakan kelompok yang harus menjadi prioritas utama dalam penanganan dengan pendekatan keadilan restoratif. Apabila diversi berhasil maka akan dilaksanakan penghentian proses hukum. ${ }^{23}$

Pada perkara anak dengan ancaman sanksi pidana sampai 1 tahun wajib mendapat prioritas dalam penerapan diskresi sehingga perkara anak tersebut tidak perlu melalui proses hukum formal. Perkara anak dngan ancaman sanksinya melebihi 1 (satu) tahun sampai batasan di bawah 7( tujuh) tahun dan bukan resividis maka yang diterapkan adalah diversi dengan pendekatan keadilan restorative.

Mengacu pada landasan filosofis penerapan diversi ini yang bertujuan memberikan perlindungan bagi anak dengan menjauhkan anak dari pidana penjara dan kurungan tentu saja tidak dapat diterapkan secara merata. Anak-anak pelaku tindak pidana ancamannya diatas 7 tahun penjara tentu saja diproses hukum tanpa melalui upaya diversi, hal ini menunjukan bahwa perlindungan hukum terhadap anak dalam upaya mencapai kesejahteraan anak tidak dapat diberikan oleh negara kepada seluruh anak Indonesia. ${ }^{24}$ Namun terdapat pengaturan pada Perma RI No. 4 Tahun 2014 yang memberikan celah dilaksanakannya diversi untuk anak yang ancaman pidananya 7 (tujuh) tahun atau lebih yaitu Pasal 3 menegaskan bahwa "Hakim anak wajib mengupayakan diversi dalam hal anak didakwa melakukan tindak pidana yang

20 Wahyudi, S., op.cit, h.59.

22 Harefa, B. (2015). Diversi Sebagai Perlindungan Hukum Terhadap Hak Asasi Anak Dalam Sistem Peradilan Pidana Anak Di Indonesia. Jurnal Komunikasi Hukum (JKH), 1(1), 1-13. DOI: http://dx.doi.org/10.23887/jkh.v1i1.5009, h.5.

23 Jafar, K. (2015). Restorative Justice Atas Diversi Dalam Penanganan Juvenile Deliquency (Anak Berkonflik Hukum). Jurnal Al-'Adl, 8(2), 81-101. DOI: http://dx.doi.org/10.31332/aladl.v8i2.361, h. 85.

24 Sambas, N. (2010), Pembaharuan Sistem Pemidanaan Anak di Indonesia. Graha Ilmu, h.26. 
diancam dengan pidana penjara di bawah 7 (tujuh) tahun dan didakwa pula dengan tindak pidana yang diancam dengan pidana penjara 7 (tujuh) tahun atau lebih dalam bentuk surat dakwaan subsidiaritas, alternatif, kumulatif maupun kombinasi (gabungan)".

UU SPPA dan peraturan pelaksananya telah mengatur mengenai konsep diversi dan keadilan restoratif yang bertujuan agar anak tidak ditangani melalui proses peradilan yang memberikan dampak buruk namun melalui penyelesaian alternatif. Terdapat ketimpangan regulasi mengenai kriteria anak yang dapat diupayakan diversi yang diatur dalam dua regulasi antara lain UU SPPA dan PERMA RI No. 4 Tahun 2014. Meskipun telah diatur PP Nomor 65 Tahun 2015 tentang Pedoman Pelaksanaan Diversi dan Penanganan Anak yang Belum Berumur 12 (dua belas) tahun, PERMA MA ini masih menjadi pedoman bagi Peradilan Umum terhadap hal-hal yang tidak diatur di dalam PP Nomor 65 Tahun 2015, dimana mengisi kekosongan hal-hal yang tidak diatur seperti apabila dakwaan bersifat alternatif atau kumulatif dengan ancaman dibawah 7 tahun maka hal ini memerlukan diversi.

Selain itu PERMA MA ini memberikan penegasan dapat dilakukannya diversi pada penanganan perkara anak yang ancaman pidananya 7 (tujuh) tahun maupun lebih dengan syarat perkara tersebut didakwa dalam dakwaan subsidair, alternatif, kumulatif dan gabungan. Sudah sepatutnya, diversi yang merupakan suatu bentuk upaya perlindungan hukum seharusnya diberikan dengan tanpa batasan-batasan yang memenjarakan kebebasan anak, namun kesempatan memperoleh proses diversi berhak didapatkan oleh semua anak yang berkonflik dengan hukum. Diversi sangat penting untuk diperhatikan dalam penanganan anak yang berkonflik dengan hukum untuk menghindarkan anak dari proses stigmatisasi yang lazimnya terjadi dalam proses pemidanaan anak lewat sistem peradilan pidana anak.

\section{Kesimpulan}

Kesimpulan dari kajian dan analisis permasalahan ini yaitu Pengaturan mengenai perlindungan terhadap anak yang berkonflik dengan hukum terdapat diberbagai peraturan perundang-undangan antara lain UU Kesejahteraan Anak, UU Perlindungan Anak, UU HAM, dan UU SPPA yang pada dasarnya memiliki tujuan yang sama yaitu menjamin dan memberikan perlindungan pada anak beserta hak-haknya agar dapat hidup, tumbuh berkembang, dan berpartisipasi secara optimal sesuai harkat dan martabat kemanusiaan serta mendapat perlindungan dari kekerasan dan diskriminasi. Sedangkan diversi merupakan bentuk perlindungan hukum bagi anak yang berkonflik dengan hukum. Penanganan anak yang berkonflik dengan hukum pada tingkat kepolisian, kejaksaan dan pemeriksaan di Pengadilan wajib diupayakan diversi. Diversi dapat mengalihkan anak yang telah melakukan pelanggaran ringan menjauhkan dari pemidanaan dan menuju perawatan berbasis masyarakat dalam mencegah kenakalan di masa depan Anak pelaku pidana yang ancaman pidananya (tujuh) tahun keatas tidak dapat diterapkan diversi apabila mengacu pada UU SPPA ini. Masih terdapat ketimpangan regulasi mengenai kriteria anak yang dapat diupayakan diversi yang diatur dalam dua regulasi antara lain UU SPPA dan Perma RI No. 4 Tahun 2014 .Pada PERMA tersebut memberikan penegasan dapat dilakukannya diversi pada perkara yang ancamannya 7 (tujuh) tahun maupun lebih dengan syarat perkara tersebut 
didakwa dalam dakwaan subsidair, alternatif, kumulatif dan gabungan. Sudah sepatutnya, diversi yang merupakan suatu bentuk upaya perlindungan hukum yang seharusnya diberikan dengan tanpa batasan-batasan yang memenjarakan kebebasan anak, namun kesempatan memperoleh proses diversi berhak didapatkan oleh semua anak yang berkonflik dengan hukum.

\section{Daftar Pustaka / Daftar Referensi}

\section{$\underline{\text { Buku }}$}

Swardhana, G.M. (2013). Kenakalan Anak \& Upaya Penanggulangannya. Udayana University Press.

Sambas, N. (2010), Pembaharuan Sistem Pemidanaan Anak di Indonesia. Graha Ilmu.

Urbas, G. (2000). The age of criminal responsibility (Vol. 181). Canberra, Australian Capital Territory: Australian Institute of Criminology.

Wahyudi, S. (2011). Implementasi ide diversi dalam pembaruan sistem peradilan pidana anak di Indonesia. Yogyakarta: Genta Pub.

\section{Jurnal}

Ananda, F. (2018). Penerapan Diversi Sebagai Upaya Perlindungan Hukum Terhadap Anak Pelaku Tindak Pidana. Jurnal Daulat Hukum, 1(1), 77-86. DOI: http://dx.doi.org/10.30659/jdh.v1i1.2566.

Budoyo, S., \& Sari, R. K. (2019). Eksistensi Restoratif Justice sebagai Tujuan Pelaksanaan Diversi pada Sistem Peradilan Anak di Indonesia. Meta-Yuridis, 2(2), 79-90. DOI: https://doi.org/10.26877/m-y.v2i2.4689.

Bramita, F., \& Cahyaningtyas, I. (2018). Children Hearing System sebagai Ide Pembaharuan Sistem Peradilan Pidana Anak di Indonesia. Jurnal Magister Hukum Udayana (Udayana Master Law Journal) 7(4), 529-545. DOI: https://doi.org/10.24843/JMHU.2018.v07.i04.p08.

Harefa, B. (2015). Diversi Sebagai Perlindungan Hukum Terhadap Hak Asasi Anak Dalam Sistem Peradilan Pidana Anak Di Indonesia. Jurnal Komunikasi Hukum (JKH), 1(1), 1-13. DOI: http://dx.doi.org/10.23887/jkh.v1i1.5009.

Hariyanto, D. R. S., \& Yustiawan, D. G. P. Paradigma Keadilan Restoratif Dalam Putusan Hakim. Kertha Patrika, 42(2), 180-191. DOI: https://doi.org/10.24843/ KP.2020.v42.i02.p06.

Jafar, K. (2015). Restorative Justice Atas Diversi Dalam Penanganan Juvenile Deliquency (Anak Berkonflik Hukum). Jurnal Al-'Adl, 8(2), 81-101. DOI: http://dx.doi.org/10.31332/aladl.v8i2.361.

Ratomi, A. (2013). Konsep Prosedur Pelaksanaan Diversi pada Tahap Penyidikan dalam Penyelesaian Tindak Pidana yang Dilakukan oleh Anak. Arena Hukum, 6(3), 394407. DOI: https://doi.org/10.21776/ub.arenahukum.2013.00603.6. 
Said, M. F. (2018). Perlindungan Hukum Anak Dalam Perspektif Hak Asasi Manusia. JCH (Jurnal Cendekia Hukum), 4(1), 141-152. DOI: http://doi.org/10.33760/ jch.v4i1.97.

Sari, M. A. C. M. (2013). Diversi dalam Sistem Peradilan Pidana Anak di Indonesia. Jurnal Magister Hukum Udayana, 2(1), 44093. DOI: https://doi.org/10.24843/ IMHU.2013.v02.i01.p05.

Sekhroni, S. (2016). Criminal Liability dan Diversi Terhadap Tindak Pidana Anak dalam Sistem Peradilan Anak di Indonesia. UNIFIKASI: Jurnal Ilmu Hukum, 3(1), 36-64. DOI: https://doi.org/10.25134/unifikasi.v3i1.405.

Sinaga, S. M., \& Lubis, E. Z. (2010). Perlindungan Hukum terhadap Anak Yang Melakukan Kejahatan dalam Persidangan Anak. Jurnal Mercatoria, 3(1), 52-57. DOI: https://doi.org/10.31289/mercatoria.v3i1.595.

Sri Utari, A.A. (2018). Efektivitas Peraturan Daerah Provinsi Bali Nomor 6 Tahun 2014 tentang Perlindungan Anak dalam Aspek Hak Anak atas Pendidikan. Jurnal Kertha Negara 6 (2), 1-10.

Sudiarawan, K. A., Tanaya, P. E., \& Hermanto, B. (2020). Discover the Legal Concept in the Sociological Study. Substantive Justice International Journal of Law, 3(1), 94-108. DOI: http://dx.doi.org/10.33096/sjijl.v3i1.69.

\section{Peraturan Perundang-Undangan}

Undang-Undang Dasar Negara Republik Indonesia Tahun 1945

Kitab Undang-Undang Hukum Pidana

Undang-Undang Nomor 11 Tahun 2012 tentang Sistem Peradilan Pidana Anak (Lembaran Negara Republik Indonesia Tahun 2012 Nomor 153, Tambahan Lembaran Negara Republik Indonesia Nomor 5332). 